\title{
DINAMIKA POLITIK HUKUM DALAM PEMENUHAN HAK ATAS KESEHATAN DI INDONESIA
}

\author{
Rico Mardiansyah \\ Kemeterian Kesehatan Republik Indonesia \\ email: rico.mardiansyah@gmail.com \\ disampaikan 29/5/18 - di-review 2/6/18 - diterima 25/6/18 \\ DOI: $10.25123 /$ vej.2918
}

\begin{abstract}
The right to health is widely recognized as basic human rights and consequently it is the state's duty to guarantee its fulfilment. The Indonesian government, in realization of this duty, develops and put in place a national health care (insurance) system, which successful working depend on citizens paying equal amount of the premium needed to sustain this public health care system. However, the same state, in the context of social justice and welfare, provide poor citizens with monetary aid. This article discusses, by using a juridical normative approach, supplemented by an inter-multi disciplinary approach, the political dynamics underpinnings influencing the social or health care system's implementation.
\end{abstract}

Keywords:

right to health, basic-human rights, Social Welfare-Justice and Insurance

\begin{abstract}
Abstrak
Hak atas kesehatan (right to health) adalah hak asasi manusia dan sebab itu Negara wajib menjamin pemenuhannya. Pemerintah Indonesia sebagai upaya untuk memenuhi hak atas kesehatan, membangun satu sistem jaminan kesehatan nasional. Sistem ini dilandaskan pada asuransi social yang mewajibkan semua peserta atau warganegara untuk membayar premi. Dengan demikian, beban atau risiko disebar dan ditanggung bersama-sama. Namun pada saat yang sama Negara, dalam rangka mewujudkan kesejahteraan dan keadilan social, memberikan bantuan keuangan atau keringanan kewajiban membayar premi pada fakir miskin dan rakyat tidak mampu. Dalam tulisan ini, yang menggunakan metoda yuridis normative yang dipadukan dengan pendekatan ilmu lain (multi-interdisiplin), akan ditelaah perkembangan politik hukum di Indonesia berkenaan dengan pemenuhan hak asasi warganegara atas kesehatan.
\end{abstract}

Kata kunci:

Hak atas kesehatan, Hak Asasi Manusia, Kesejahteraan-Keadilan-Asuransi Sosial

\section{Pendahuluan}

Pada beberapa Konvensi Internasional dan dokumen hukum internasional, ketentuan mengenai hak atas kesehatan ditetapkan sebagai salah satu hak dasar (hak fundamental) yang dimiliki oleh setiap individu. Ketentuan hak atas kesehatan yang merupakan hak fundamental yang dimiliki oleh setiap individu di antaranya tercantum dalam pembukaan World Health Organization (WHO) 
Constitution yang berbunyi: The enjoyment of the highest attainable standard of health is one of the fundamental rights of every human being without distinction of race, religion, political belief, economic or social conditions. ${ }^{1}$ Dengan demikian hak atas kesehatan sebagai salah satu hak dasar yang dimiliki oleh setiap individu harus dihormati dan dipenuhi oleh negara tanpa membedakan suku, agama, latar belakang politik, ekonomi maupun kondisi sosial.

Berdasarkan hal tersebut hak atas kesehatan diakui sebagai "hak dasar" oleh masyarakat internasional sejak adopsi dari Konstitusi Organisasi Kesehatan Dunia (WHO) pada tahun 1946. ${ }^{2}$ Kemudian dipertegas dalam komentar umum dari Komite Hak-hak Ekonomi, Sosial, dan Budaya ${ }^{3}$ terhadap hak atas kesehatan yaitu "Health is a fundamental human right indispensable for the exercise of other human rights. ${ }^{4}$ Berdasarkan komentar umum dari Komite Hak-hak Ekonomi, Sosial, dan Budaya, kesehatan ditempatkan sebagai hak asasi manusia yang fundamental dan tak ternilai demi terlaksananya hak asasi manusia yang lainnya.

Maka sudah selayaknya hak atas kesehatan dihormati dan dilaksanakan oleh negara sebagai salah satu hak yang mendasar (fundamental). Kewajiban negara dalam memberikan perlindungan terhadap hak atas kesehatan yang dimiliki oleh seluruh warga negara sejalan dengan apa yang dinyatakan oleh WHO yaitu negara dalam hal ini pemerintah mempunyai tanggung jawab terhadap kesehatan dari warga negaranya. Menurut WHO, "government has a responsibility

\footnotetext{
1 Virginia A. Leary, The Right to Health in International Human Right Law, Health and Human Right Vol 1 No.1, The President and Fellows of Harvard College, hlm 32.

2 Id, hlm 25.

3 Komite Hak-Hak Ekonomi, Sosial, dan Budaya merupakan komite yang bertugas memantau penerapan Kovenan hak-hak ekonomi, sosial, dan budaya oleh negara pihak melalui perspektif internasional yang beranggotakan 18 orang terdiri dari para ahli dengan kemampuan yang telah diakui dalam bidang hak asasi manusia. Anggota Komite adalah orang-orang yang independen dan mengabdi berdasarkan kemampuannya masing-masing, bukan merupakan perwakilan dari pemerintahnya.

4 CESCR General Comment No 14: The Right To The Highest Attainable Standard Of Health, (Commitee on Social and Cultural Rights, 2000), hlm 1.
} 
for the health of their people which can be fulfilled only by the provision of adequate health and social measures". 5

Sebagai hak dasar yang harus dihormati dan dipenuhi oleh negara, maka hak atas kesehatan pada dasarnya mempunyai kedudukan yang sama dengan hakhak fundamental lainnya, hal tersebut sesuai dengan apa yang dinyatakan oleh Paul Hunt yaitu: Although the right to health is a fundamental human right that has the same international legal status as freedom of religion or the right to a fair trial, it is not as widely recognized as these and other civil and political rights. ${ }^{6}$ Dengan demikian hak atas kesehatan sebagai hak fundamental memiliki kedudukan yang sama dengan kebebasan beragama maupun hak-hak dasar lainnya, walaupun hak atas kesehatan belum dikenal secara luas sebagai hak asasi manusia.

Hak atas kesehatan sebagai hak fundamental yang menuntut tanggung jawab negara dalam pemenuhannnya dipertegas kembali dalam deklarasi yang dilakukan oleh WHO dan UNICEF yang dikenal sebagai deklarasi Almaata, yaitu: The important WHO and UNICEF Declaration of Almaata adopted at the International Conference on Primary Health Care in 1978, also used similar language: The Conference strongly reaffirms that health, which is a state of complete physical, mental and social wellbeing, and not merely the absence of disease or infirmity, is a fundamental human right and that the attainment of the highest possible level of health is a most important world-wide social goal whose realization requires the action of many other social and economic sectors in addition to the health sector. ${ }^{7}$ Konferensi tersebut menegaskan kembali hak atas kesehatan yang merupakan bagian dari hak asasi manusia, di mana pemenuhan hak atas kesehatan merupakan tanggung jawab negara dan tujuan dari seluruh dunia yang juga harus didukung oleh berbagai sektor.

Apabila kita melihat kepada konvensi-konvensi internasional, maka terkait dengan pemenuhan hak atas kesehatan, Universal Declaration IOndependent of

5 Koeswadji, dalam Tinton Slamet Kurnia, Hak Atas Derajat Kesehatan Optimal Sebagai HAM di Indonesia, PT. Alumni, Bandung, hlm 15.

${ }^{6}$ Paul Hunt, "The UN Special Rapporteur on The Right to Health: Key Objectives, Themes, and Intervention", Health and Human Right Vol 7 No.1, The President and Fellows of Harvard College, hlm 4.

7 Virginia A. Leary, Supra no 1, hlm 32-33. 
Human Right (Deklarasi Universal Hak Asasi Manusia) merupakan titik awal hak atas kesehatan dinyatakan sebagai bagian dari hak asasi manusia. Pada Deklarasi Universal Hak Asasi Manusia Pasal 25 ayat (1) dinyatakan bahwa setiap orang berhak atas taraf hidup yang memadai untuk kesehatan dan kesejahteraan dirinya dan keluarganya, termasuk hak atas pangan, pakaian, perumahan, dan perawatan kesehatan serta pelayanan sosial yang diperlukan. ${ }^{8}$

Ketentuan mengenai hak atas kesehatan selanjutnya berkembang pada hak asasi manusia generasi kedua, yaitu ditandai dengan ditetapkannya International Convenant on Economic, Social, and Cultural Rights dan International Convenant on Civil dan Political Rights. Pada Universal Declaration of Human Rights (1948), perwakilan dari berbagai negara sepakat untuk mendukung hak-hak yang terdapat di dalamnya "as a common standard of achievement for all peoples and all nation". Kemudian Pada tahun 1976, International Convenant on Economic, Social, and Cultural Rights dan International Convenant on Civil dan Political Rights disetujui Majelis Umum PBB dan dinyatakan berlaku. ${ }^{9}$

Dalam penjabaran di atas tampak bahwa perkembangan hak atas kesehatan sebagaimana dimaksud tidak terlepas dari perkembangan hak asasi manusia di dunia internasional. Di Indonesia sendiri konsep hak asasi manusia berkembang pada masa reformasi dimana wacana untuk melakukan perubahan atau amandemen UUD 1945 direalisasikan melalui beberapa tahapan perubahan. Begitu juga dengan konsep mengenai hak asasi manusia, tertuang dalam UUD 1945 dalam beberapa tahapan perubahan atau amandeman UUD 1945. Masuknya konsep hak asasi manusia dalam UUD 1945 bermula pada amandemen kedua Konstitusi tahun 2000, pada Bab XA Undang-Undang Dasar 1945 tertuang ketentuan tentang hak asasi manusia. Sebagian besar dari ketentuan yang baru tersebut berkaca pada hak-hak yang terkandung dalam perjanjian-perjanjian hak asasi manusia (konvensi internasional). Hak-hak tersebut termasuk hak-hak sipil dan politik (pasal 28A), perlakuan yang sama di hadapan hukum (Pasal 28D), hak

8 Universal Declaration Independent of Human Right (Deklarasi Universal Hak Asasi Manusia/DUHAM).

9 Satya Arinanto, Hak Asasi Manusia dalam Transisi Politik di Indonesia, Pusat Studi Hukum Tata Negara Fakultas Hukum Universitas Indonesia, Jakarta, hlm 77-78. 
atas lingkungan yang sehat dan memperoleh pelayanan kesehatan (Pasal 28H ayat (1)), dan hak atas jaminan sosial (Pasal 28H ayat (3)). ${ }^{10}$

Masuknya hal-hal yang berkaitan dengan hak asasi manusia ke dalam Konstitusi Indonesia berlanjut melalui amandemen ke-empat Konstitusi pada tahun 2002. Amandemen Ke-empat mendatangkan kewajiban-kewajiban negara yang bahkan lebih berat terkait dengan pemenuhan hak-hak ekonomi, sosial, dan budaya. ${ }^{11}$ Pemenuhan hak-hak ekonomi sosial, dan budaya merupakan bagian dari hak asasi manusia generasi kedua yang menitik beratkan pada konsep "persamaan". Hak-hak tersebut muncul dari tuntutan agar negara menyediakan pemenuhan terhadap kebutuhan dasar setiap orang, mulai dari makan sampai pada kesehatan. Negara dengan demikian dituntut bertindak lebih aktif, agar hakhak tersebut dapat dipenuhi atau tersedia. Karena itu hak-hak generasi kedua ini dirumuskan dalam bahasa yang positif: "hak atas" (right to), bukan dalam bahasa negatif: "bebas dari" (freedom from). ${ }^{12}$

Paul Hunt dalam tulisannnya terkait laporan PBB (United Nations) menekankan beberapa elemen penting dari hak atas kesehatan, yaitu: the right to health gives rise to responsibilities in relation to international assistance and cooperation: States have an obligation to take steps, individually and through international assistance and cooperation, toward the full realization of the right to health. ${ }^{13}$ Dengan demikian negara mempunyai kewajiban untuk mengambil langkah-langkah, secara individual maupun melalui bantuan dan kerjasama internasional guna mewujudkan realisasi terhadap pemenuhan hak atas kesehatan. Dalam arti itu, dapat dikatakan bahwa konsepsi hak atas kesehatan merupakan bagian dari keberagaman sistem hukum nasional yang mengacu atau mengikuti kaidah-kaidah hukum internasional tentang hak asasi manusia. ${ }^{14}$

\footnotetext{
10 Human Rights Resource Center, Rule of Law untuk Hak Asasi Manusia di Kawasan Asean: Studi Data Awal, Human Right Resource Center, hlm 107.

11 Id, hlm. 108.

12 Rhona K.M. Smith, at.al, Hukum Hak Asasi Manusia, PUSHAM UII, Yogyakarta, 2008, hlm 15-16.

13 Paul Hunt, Supra no 6, hlm 4.

${ }^{14}$ Sunaryati Hartono, Membangun Budaya Hukum Pancasila sebagai Bagian dari Sistem Hukum Nasional di Abad 21, 1 Veritas et Justitia, 2015, hlm. 259.
} 
Dalam hal ini Negara telah menetapkan langkah-langkah untuk merealisasikan pemenuhan hak atas kesehatan melalui Jaminan Kesehatan Nasional yang merupakan bagian dari Sistem Jaminan Sosial Nasional. Namun demikian Jaminan Kesehatan bagi setiap individu (warga negara) seharusnya menjadi kewajiban dari negara untuk memenuhinya tanpa membedakan warga negara yang satu dengan yang lainnya. Pada pelaksanaan jaminan kesehatan nasional konsep yang digunakan ialah konsep asuransi kesehatan sosial yang mencakup seluruh masyarakat, dalam hal ini kepesertaan bersifat wajib bagi seluruh rakyat Indonesia (warga negara). Sesuai basis kepesertaan tersebut maka ditetapkan iuran bagi seluruh peserta, dalam hal ini negara membagi manjadi 2 (dua) bentuk kepesertaan yaitu Penerima Bantuan Iuaran (PBI) jaminan kesehatan dan Bukan Penerima Bantuan Iuran (Bukan PBI) Jaminan Kesehatan. Penerima bantuan iuran jaminan kesehatan meliputi orang yang tergolong fakir miskin dan orang tidak mampu yang iurannya dibayarkan oleh negara, sedangkan Bukan Penerima Bantuan Iuran Jaminan Kesehatan merupakan peserta yang tidak tergolong fakir miskin dan orang tidak mampu yang iurannya tidak dibayarkan oleh negara. Berdasarkan hal tersebut maka tampak negara memberikan perlakuan yang berbeda terhadap warga negaranya dalam pemberlakuan jaminan kesehatan yaitu bagi peserta yang tergolong fakir miskin dan orang tidak mampu dan peserta yang tidak tergolong fakir miskin dan orang tidak mampu, dimana jaminan kesehatan bagi setiap individu (warga negara) seharusnya menjadi kewajiban dari negara untuk memenuhinya tanpa membedakan warga negara yang satu dengan yang lainnya. Permasalahannya bagaimana pelaksanaan jaminan kesehatan nasional yang berkeadilan dalam pelayanan kesehatan bagi setiap individu. Tulisan ini akan mencoba mengkaji permasalahan yang diuraikan tersebut di atas.

\section{Pembahasan}

\section{Hak Atas Kesehatan}

Harus disadari bahwa hidup dan kebebasan manusia akan menjadi tanpa makna jika kesehatannya tidak terurus. Karena itu, kesehatan sebagai isu hak 
asasi manusia, dalam hal ini hak atas derajat kesehatan yang optimal, dengan konsekuensi setiap manusia berhak atas derajat kesehatan yang optimal dan negara berkewajiban memenuhi hak tersebut. ${ }^{15}$

Kesehatan merupakan isu krusial yang harus dihadapi setiap negara karena berkolerasi langsung dengan pengembangan integritas pribadi setiap individu supaya dapat hidup bermartabat (kesehatan, bersama-sama dengan taraf pendidikan dan daya beli masyarakat, merupakan komponen penilaian capaian Human Development Index negara-negara di dunia). ${ }^{16}$

Secara filosofis, kesehatan sebagai hak setiap manusia, dan kewajiban negara memenuhi hak itu terutama pada situasi bahwa tidak setiap orang mempunyai kesempatan yang sama untuk menikmati haknya itu, merupakan isu keadilan. Karena hubungan erat antara isu kesehatan, keadilan dan hak asasi manusia, dengan sendirinya fungsi hukum menjadi sangat pivotal. ${ }^{17}$

Hak atas derajat kesehatan yang optimal sebagai salah satu jenis hak asasi manusia telah diakui dalam aturan hukum nasional Indonesia maupun hukum internasional, diantaranya yaitu: 18

1. Pasal 28H ayat (1) dan (3) jo. Pasal 34 ayat (3) Undang-Undang Dasar 1945

2. Pasal 4 Undang-Undang Nomor 36 tahun 2009 tentang Kesehatan

3. Pasal 40,41,42,49 dan 62 Undang-Undang Nomor 39 tahun 1999 tentang Hak Asasi Manusia

4. Pasal 25 ayat (1) Universal Declaration of Human Right

5. Pasal 12 International Convenant on Economic, Social and Cultural Right

Konsep kesehatan akan memiliki muatan normatif sebagai konsep hukum jika konsep kesehatan menyandang predikat yuridis tertentu, dalam hal ini hak, yaitu sebagai hak asasi manusia. ${ }^{19}$ Berkaitan dengan hak atas kesehatan tersebut, World Health Organization (WHO) menyatakan "the enjoyment of the highest attainable standar of health is one of the fundamental right of every human being

\footnotetext{
15 Tinton Slamet Kurnia, Hak Atas Derajat Kesehatan Optimal Sebagai HAM di Indonesia, PT. Alumni, Bandung, hlm 2

16 Id, hlm 2

17 Id.

${ }^{18}$ Human Rights Resource Center, Supra no 10, hlm 107

19 Tinton Slamet Kurnia, Supra no 15, hlm 11
} 
without distinction oe race, religion, political belief, economic or social condition".20 Sebagai salah satu hak yang mendasar (fundamental), maka sudah selayaknya hak tersebut dihormati dan dilaksanakan oleh negara. kewajiban negara dalam memberikan perlindungan terhadap hak atas kesehatan yang dimiliki oleh seluruh warga negara sejalan dengan apa yang dinyatakan oleh WHO yaitu Negara dalam hal ini Pemerintah mempunyai tanggung jawab terhadap kesehatan dari warga negaranya. Menurut WHO, "government have a responsibility for the health of their people which can be fulfilled only by the provision of adequate health and social measures".21

\section{Keadilan Sosial}

Menurut Aristoteles, hukum merupakan instrument untuk mewujudkan keadilan karena 'law can be determined only in relation to the just'. Bertolak dari pengertian ini Aristoteles sampai pada pembedaan konsep keadilan distibutif dan keadilan korektif: "Distibutiv justice is concerned with the distribution of honor, wealth, and other good as may be shared by the members of the community".22

Pelaksana utama keadilan distributif adalah negara. Negara melakukan distribusi/alokasi nilai-nilai dasar yang dianggap penting dalam suatu masyarakat (gagasan yang sangat kuat dipengaruhi konsep Welfare State) atau sebatas melakukan pengaturan dalam rangka menjamin supaya distribusi/alokasi itu berlangsung secara adil. ${ }^{23}$

Sedangkan menurut Rawls, keadilan sebagai 'fairness', yang menekankan kepada aspek persamaan faktual. Menurut Rawls, keadilan harus mampu memberikan kesempatan yang 'fair' serta hak yang sama bagi semua anggota masyarakat untuk berpartisipasi dalam setiap proses pengambilan keputusan politik dan ekonomi. Untuk itu diperlukan prosedur yang 'fair', semua pihak terkait dalam proses pemilihan prinsip-prinsip keadilan harus berada dalam posisi asli (original position). Teori Rawls tidak berbeda jalan dengan sila $\mathrm{V}$

\footnotetext{
20 Tinton Slamet Kurnia, Supra no 10, hlm. 14

21 Tinton Slamet Kurnia, Supra no 10, hlm. 15

22 Tinton Slamet Kurnia, Supra no 10, hlm. 2

${ }^{23}$ Tinton Slamet Kurnia, Supra no 10, hlm. 3
} 
Pancasila yang menyatakan Keadilan sosial Bagi Seluruh Rakyat Indonesia. Semangat inilah yang harus membimbing dan menjiwai distribusi akses layanan kesehatan dari negara kepada rakyatnya, termasuk untuk melindungi dari bahaya yang mengancam kesehatannya. ${ }^{24}$

Pada sisi lain Lorry Gostin menggunakan istilah substantive justice dalam hal pemenuhan kesehatan. Menurut Gostin, keadilan subtantif dalam masalah kesehatan berkenaan dengan the just distribution of health benefit and burdens. ${ }^{25}$ Prinsip umum yang tersembunyi dalam berbagai penerapan konsep keadilan adalah bahwa para individu dihadapan yang lainnya berhak atas kedudukan relatif berupa kesetaraaan atau ketidaksetaraan tertentu. ini merupakan sesuatu yang harus dipertimbangkan dalam ketidakpastian kehidupan sosial ketika beban atau manfaat hendak didistribusikan; ini juga merupakan sesuatu yang harus dipulihkan ketika terganggu. Dari situlah menurut tradisi keadilan dipandang sebagai pemeliharaan atau pemulihan keseimbangan (balance) atau jatah bagian (proportion). ${ }^{26}$

\section{Tugas Negara Dalam Mewujudkan Hak Atas Kesehatan}

Tugas negara menurut faham modern sekarang ini (dalam suatu Negara Kesejahteraan atau Social Service State), adalah menyelenggarakan kepentingan umum untuk memberikan kemakmuran dan kesejahteraan yang sebesar-besarnya berdasarkan keadilan dalam suatu Negara Hukum. ${ }^{27}$ Dalam hal ini tujuan negara (staatswill) menunjukkan apa yang ideal hendak dicapai oleh negara itu, sedangkan fungsi negara adalah pelaksanaan tujuan ideal itu dalam kenyataan konkret. $^{28}$

24 Tinton Slamet Kurnia, Supra no 10, hlm. 3-5

25 Tinton Slamet Kurnia, Supra no 10, hlm. 3

${ }^{26}$ H.L.A Hart, Konsep Hukum (The Concept of Law), Nusa Media, Bandung, hlm., 246

${ }^{27}$ Amrah Muslimin, Beberapa Asas dan Pengertian Pokok Tentang Administrasi dan Hukum Administrasi, Alumni, Bandung, 1985, hlm. 110.

${ }^{28}$ Hendra Nutjahjo, Ilmu Negara: Pengembangan Teori Bernegara dan Supleman, PT. Raja Grafindo Persada, Jakarta, 2005, hlm. 71. 
Falsafah dasar dari jaminan hak kesehatan sebagai HAM merupakan raison d'etre kemartabatan manusia (human dignity). ${ }^{29}$ Dimana kesehatan masyarakat adalah pilar pembangun sebuah bangsa. Derajat dan martabat sebuah bangsa akan terukur dari sejauh mana peran sosial yang dimainkan. Rendahnya kualitas kesehatan akan berdampak buruk bagi terselenggaranya roda pemerintahan. Kesadaran ini merupakan wujud komitmen semua negara bangsa. ${ }^{30}$ Berdasarkan hal tersebut maka sudah seharusnya negara menjalankan fungsinya dalam mewujudkan hak atas kesehatan antara lain obligation of conduct dan obligation of result yang merupakan bagian dari pelaksanaan hak-hak ekonomi, sosial, dan budaya. ${ }^{31}$

Salah satu prinsip dalam hukum intenasional yang berlaku bagi seluruh negara yang tertuang dalam berbagai konvensi internasional dan tercantum dalam Konstitusi WHO menyatakan "The enjoyment of the highest attainable standard of health as a fundamental right of every human being". Prinsip tersebut memberikan landasan bagi setiap negara dalam membuat sebuah kebijakan yang harus dapat mewujudkan hak atas kesehatan bagi setiap individu, dimana hak atas derajat kesehatan yang optimal merupakan hak dasar bagi setiap individu. Dalam hal ini negara dituntut untuk melakukan penghormatan, pemenuhan dan perlindungan terhadap hak atas kesehatan. Aspek penghormatan sebagaimana dimaksud ialah kebijakan yang mengharuskan negara untuk tidak mengambil langkah-langkah yang akan mengakibatkan individu atau kelompok gagal meraih atau memenuhi hak-haknya. Sementara pemenuhan adalah negara harus mengambil tindakan legislatif, administratif, anggaran, yudisial atau langkahlangkah lain untuk memastikan terealisasinya pemenuhan hak-hak. Sedangkan perlindungan adalah bagaimana negara melakukan kebijakan guna mencegah dan menanggulangi dilakukannya pelanggaran sengaja atau pembiaran. ${ }^{32}$

\footnotetext{
29 Majda El Muhtaj, Dimensi-Dimensi HAM: Mengurai Hak Ekonomi, Sosial, dan Budaya, Rajawali Pers, Jakarta, 2009, hlm 152.

$30 \mathrm{Id}, \mathrm{hlm} .157$.

31 Id, hlm. xxx.

32 Suparman Marzuki, Politik Hukum HAM Di Indonesia, Makalah disampaikan dalam Pelatihan HAM Dasar Bagi Dosen Hukum HAM Se-Indonesia, Surabaya, 10 - 13 Oktober 2011, hlm 1.
} 
Salah satu agenda yang memperkuat kedudukan hak asasi manusia yang dimiliki oleh setiap individu, dimana negara bertugas untuk mewujudkannya terdapat dalam Deklarasi Vienna yang menyatakan "All human rights are universal, indivisible and interdependent and interrelated. The international community must treat human rights globally in a fair and equal manner, on the same footing, and with the same emphasis. While the significance of national and regional particularities and various historical, cultural and religious backgrounds must be borne in mind, it is the duty of States, regardless of their political, economic and cultural systems, to promote and protect all human rights and fundamental freedoms". ${ }^{33}$ Karena sifatnya yang universal dan saling berkaitan antara hak yang satu dengan hak yang lain, maka pemenuhan dan perlindungan hak asasi manusia merupakan tugas negara yang harus dipenuhi terhadap seluruh individu. Hak atas kesehatan sebagai hak asasi manusia harus dipenuhi oleh negara sesuai dengan konvensi yang berlaku secara universal. Dalam hal ini hak asasi manusia menetapkan standar minimum, dimana hak asasi manusia tidak mencoba untuk menggambarkan suatu dunia sosial dan politik yang ideal. Pemberlakuan hak asasi manusia memberikan ruang keputusan yang paling politik di tangan para pemimpin nasional dan seluruh warga negara. Namun secara garis besar dalam pelaksanaannya, hak asasi manusia menuntut standar yang memberlakukan batasan yang signifikan pada undang-undang dan pembuatan kebijakan yang mengarah kepada pemenuhan dan penghormatan terhadap hak-hak asasi manusia. ${ }^{34}$

Negara merupakan aktor sentral yang memegang tanggung jawab utama dalam pelaksanaan kebijakan yang berdasarkan hukum internasional atau perjanjian internasional dimana hak atas kesehatan dilindungi. ${ }^{35}$ Dalam melakukan upaya tersebut negara harus mengambil langkah-langkah yang strategis dalam pemenuhan hak atas kesehatan, dengan melibatkan seluruh

\footnotetext{
33 lihat Vienna Declaration and Programme of Action adopted at the World Conference on Human Rights, Vienna, 14-25 June 1993, paragraph 5, (United Nations General Assembly document A/ CONF. 137/23).

34 James W. Nickle, Making Sense Of Human Right, Blackwell Publishing, hlm. 10.

35 Jhon Tobin, The Right to Health in International Law, Oxford University Press New York, hlm. 84.
} 
stakeholder dalam bidang kesehatan baik dari unsur pemerintah maupun dari unsur swasta. Dalam hal ini hak atas kesehatan sebagai sebuah hak asasi manusia secara hukum melahirkan hubungan antara individu dengan negara, dimana kewajiban negara berkaitan dengan hak asasi manusia harus mengacu kepada tiga prinsip yaitu menghormati (respect), melindungi (protect), dan memenuhi (fulfil) hak atas kesehatan yang merupakan bagian dari hak asasi manusia. ${ }^{36}$

\section{Konsepsi Hak Atas Kesehatan Dalam Sistem Jaminan Sosial Nasional}

Kebijakan pemenuhan Hak atas kesehatan dalam hal ini hak atas pelayanan kesehatan (right to care) di Indonesia merupakan bagian dari Sistem Jaminan Sosial Nasional. Dimana landasan penyusunan Kebijakan Sistem Jaminan Sosial Nasional bermula dari sidang Majelis Permusyawaratan Rakyat yang membahas laporan Lembaga Tinggi Negara pada tahun 2001 dan kondisi terkini yang terjadi di Indonesia dan Dunia. Pada saat itu MPR menyatakan bahwa Krisis nasional yang bermula dari krisis moneter, krisis ekonomi, krisis politik, krisis keamanan, dan krisis kepercayaan yang melanda bangsa Indonesia sejak tahun 1997 telah sampai pada keadaan yang dapat membahayakan kelangsungan hidup bangsa dan negara Republik Indonesia. Keadaan tersebut semakin sulit dengan munculnya ancaman resesi ekonomi dunia. Untuk mengatasi keadaan yang sangat berat tersebut diperlukan tekad, komitmen dan kebersamaan yang kuat dari seluruh komponen bangsa, khususnya para penyelenggara negara. ${ }^{37}$ Berdasarkan hal tersebut di atas dan setelah mendengar serta membahas laporan lembaga Tinggi Negara dan Pandangan Umum Fraksi-fraksi Majelis dalam Sidang Tahunan 2001, maka Majelis Permusyawaratan Rakyat Republik Indonesia memberikan penugasan kepada Presiden dan rekomendasi kepada Lembaga Tinggi Negara melalui Ketetapan Majelis Permusyawaratan Rakyat Republik Indonesia Nomor: X/MPR/2001 Tentang Laporan Pelaksanaan Putusan Majelis Permusyawaratan

\footnotetext{
36 lihat World Health Organization, 25 Question and Answer on Health and Human Rights, Health and Human Rights Publication Series, Issue No. 1, Geneva, 2002, hlm 9.

37 Lihat pendahuluan dalam Ketetapan Majelis Permusyawaratan Rakyat Republik Indonesia Nomor: X/Mpr/2001 tentang Laporan Pelaksanaan Putusan Majelis Permusyawaratan Rakyat Republik Indonesia Oleh Lembaga Tinggi Negara Pada Sidang Tahunan Majelis Permusyawaratan Rakyat Republik Indonesia Tahun 2001.
} 
Rakyat Republik Indonesia Oleh Lembaga Tinggi Negara Pada Sidang Tahunan Majelis Permusyawaratan Rakyat Republik Indonesia Tahun 2001. Penugasan kepada Presiden oleh MPR yang terdapat dalam Tap MPR Nomor: X/Mpr/2001 terdiri dari berbagai bidang pemerintahan yang terdiri dari:
a. Politik dan Keamanan;
b. Ekonomi dan Keuangan;
c. Hukum dan Hak Asasi Manusia;
d. Agama; dan
e. Sosial dan Budaya.

Dalam hal ini sistem Jaminan Sosial Nasional merupakan bagian dari penugasan MPR kepada Presiden yang termasuk ke dalam penugasan dalam bidang sosial dan budaya $^{38}$. MPR pada saat itu berpandangan bahwa meningkatnya jumlah tenaga kerja dan meluasnya pengangguran telah menimbulkan implikasi sosial yang kompleks seperti munculnya tindakan anarkistis, kriminalitas dan kejahatan lainnya yang meresahkan masyarakat, selain itu dampak krisis nasional yang berkepanjangan telah menimbulkan banyak pemutusan hubungan kerja (PHK) yang telah memperluas keresahan dalam masyarakat sehingga memerlukan penanganan secara komprehensif. Berdasarkan pandangan yang disampaikan oleh MPR, maka MPR menugaskan kepada Presiden untuk melakukan 2 (dua) langkah konkrit yaitu:

1. Mengusahakan suatu crash program yang aplikatif secara langsung menyentuh kepentingan masyarakat sehubungan dengan tahapan penyediaan lapangan kerja dan kesempatan berusaha.

2. Membentuk sistem jaminan sosial nasional dalam rangka memberi perlindungan sosial yang lebih menyeluruh dan terpadu.

\footnotetext{
38 penugasan MPR kepada Presiden yang terdapat dalam Ketetapan Majelis Permusyawaratan Rakyat Republik Indonesia Nomor: X/Mpr/2001 Tentang Laporan Pelaksanaan Putusan Majelis Permusyawaratan Rakyat Republik Indonesia Oleh Lembaga Tinggi Negara Pada Sidang Tahunan Majelis Permusyawaratan Rakyat Republik Indonesia Tahun 2001 yang termasuk kedalam penugasan dalam bidang sosial dan budaya diantaranya yaitu penugasan dalam Pelayanan Kesehatan, Pendidikan, Pemuda dan Olah Raga, Budaya dan pariwisata, Tenaga Kerja dan Jaminan Sosial, Perdagangan Perempuan dan Anak, Pornografi, Pengungsi, serta Narkotika, Psikotropika dan Zat Adiktif lainnya.
} 
Selain itu di sisi lain MPR juga menugaskan Presiden dalam upaya melakukan peningkatan pelayanan kesehatan. MPR pada saat itu berpandangan bahwa pelayanan kesehatan belum dapat diberikan secara optimal, terutama masalah penanganan krisis gizi dan berjangkitnya penyakit menular di daerah pengungsian dan di daerah konflik serta yang mengalami bencana alam. Berdasarkan pandangan yang disampaikan oleh MPR, maka MPR menugaskan kepada Presiden untuk melakukan

1. Secepatnya membuat program darurat (crash program) pelayanan kesehatan.

2. Menggalang partisipasi dan swadaya masyarakat untuk bersama pemerintah melaksanakan program darurat.

3. Memperhatikan dengan sungguh-sungguh krisis gizi khususnya pada ibu hamil, bayi dan balita.

4. Mengupayakan peningkatan anggaran kesehatan 15\% dari APBN, untuk mencapai syarat minimum HDI (Human Development Index) yang ditetapkan oleh WHO.

Pada Sidang Tahunan Majelis Permusyawaratan Rakyat Republik Indonesia Tahun 2001 yang dilaksanakan antara MPR dengan Lembaga Tinggi Negara lainnya juga membahas tentang isu Hak Asasi Manusia. Isu atau pembahasan hak asasi manusia pada Sidang Tahunan Majelis Permusyawaratan Rakyat Republik Indonesia Tahun 2001 pada akhirnya memunculkan penugasan dalam ruang lingkup Hak Asasi Manusia yang tertuang dalam Bidang Hukum dan Hak Asasi Manusia $^{39}$, Ketetapan Majelis Permusyawaratan Rakyat Republik Indonesia Nomor: X/Mpr/2001 menugaskan kepada presiden untuk segera menyelesaikan proses penyidikan dan penuntutan perkara-perkara dugaan pelanggaran Hak Asasi Manusia.

\footnotetext{
39 penugasan MPR kepada Presiden yang terdapat dalam Ketetapan Majelis Permusyawaratan Rakyat Republik Indonesia Nomor: X/Mpr/2001 Tentang Laporan Pelaksanaan Putusan Majelis Permusyawaratan Rakyat Republik Indonesia Oleh Lembaga Tinggi Negara Pada Sidang Tahunan Majelis Permusyawaratan Rakyat Republik Indonesia Tahun 2001 yang termasuk kedalam penugasan dalam bidang hukum dan hak asasi manusia diantaranya yaitu penugasan dalam Pemberantasan Korupsi, Kolusi, dan Nepotisme; Penegakan Hukum; Penyelesaian Kasuskasus Pelanggaran Hak Asasi Manusia; Pembentukan Komisi Kebenaran dan Rekonsiliasi.
} 
Dari uraian di atas tampak bahwa topik pembahasan kesehatan dan jaminan sosial tidak masuk dalam bidang hukum dan hak asasi manusia akan tetapi justru masuk dalam bidang sosial dan budaya, dimana jaminan sosial masuk dalam "penugasan lingkup tenaga kerja dan jaminan sosial" serta kesehatan masuk ke dalam "penugasan lingkup pelayanan kesehatan".

Pada awalnya Kebijakan pemenuhan Hak atas kesehatan dalam hal ini hak atas pelayanan kesehatan (right to care) di Indonesia terpisah dari Sistem Jaminan Sosial Nasional, kebijakan yang dirancang terhadap pemenuhan hak atas kesehatan tersebut merupakan konsep asuransi kesehatan sosial yang mencakup seluruh masyarakat yang mengadopsi konsep asuransi sosial. Hak atas kesehatan yang dirancang dalam konsep asuransi kesehatan sosial disusun sebagai sub sistem dalam Sistem Jaminan Sosial Nasional dimana konsep jaminan sosial akan ditetapkan dalam peraturan yang berbeda, namun pembahasan di DPR menyepakati bahwa Asuransi Kesehatan Sosial di lebur dalam Sistem Jaminan Sosial Nasional.

Dengan demikian meleburnya hak atas kesehatan dengan hak atas jaminan sosial yang kedua-duanya juga tercantum dalam Undang-Undang Dasar 1945 tampak dari Laporan ketua Pansus Rancangan Undang-Undang Tentang Sistem Jaminan Sosial Nasional dalam rapat paripurna DPR RI yang dilaksanakan pada tanggal 28 September 2004 menyatakan bahwa rancangan undang-undang tentang Sistem Jaminan Sosial Nasional merupakan amanat dari Undang-Undang Dasar Negara Republik Indonesia Tahun 1945 Pasal 28 H ayat (1), ayat (2) dan ayat (3) mengenai hak terhadap jaminan sosial dan hak atas kesehatan. Secara lebih khusus, Pasal 34 ayat (2) UUD 1945 menegaskan bahwa Negara mengembangkan Sistem Jaminan Sosial Nasional. Sistem tersebut dimaksudkan untuk memberikan jaminan sosial yang menyeluruh karena setiap orang berhak atas jaminan sosial untuk dapat memenuhi kebutuhan dasar hidup yang layak, 
meningkatkan martabatnya demi terwujudnya masyarakat Indonesia yang sejahtera, adil, dan makmur. ${ }^{40}$

Selain itu meleburnya Jaminan Kesehatan dengan Jaminan Sosial juga dipertegas oleh Pemerintah yang disampaikan dalam penjelasan Pemerintah sebagai pengantar Rancangan Undang-Undang yang menyatakan Bahwa SJSN meliputi pula jaminan kesehatan yang diselenggarakan dengan mekanisme asuransi sosial. Pengaturan sistem jaminan kesehatan sebagai subsistem dari Sistem Jaminan Sosial Nasional sekaligus dimaksudkan untuk mengatur sistem asuransi kesehatan sosial nasional sebagaimana diajukan dalam bentuk rancangan Undang-Undang tentang Asuransi Kesehatan Sosial Nasional oleh DPR. Dengan demikian, tidak perlu lagi disusun sebuah Undang-Undang tersendiri mengenai asuransi sosial nasional. ${ }^{41}$

Oleh karena itu jaminan kesehatan melebur dalam program jaminan sosial, hal tersebut sesuai dengan Undang-Undang Nomor 40 tahun 2004 tentang Sistem Jaminan Sosial Nasional Pasal 18 yang menyatakan bahwa jenis program jaminan sosial meliputi jaminan kesehatan, jaminan kecelakaan kerja, jaminan hari tua, jaminan pensiun, dan jaminan kematian. Dalam hal ini jaminan kesehatan diselenggarakan dengan tujuan menjamin agar peserta memperoleh manfaat pemeliharaan kesehatan dan perlindungan dalam memenuhi kebutuhan dasar kesehatan. ${ }^{4}$

\section{Pemenuhan Hak Atas Kesehatan Melalui Jaminan Kesehatan Nasional}

Sejak tahun 1947, Deklarasi Hak Asasi Manusia Perserikatan Bangsabangsa (PBB) telah menempatkan kesehatan sebagai salah satu hak asasi dan menyebutkan bahwa "setiap penduduk berhak atas jaminan manakala ia sakit". Untuk itu, Indonesia sebagai negara yang telah meratifikasi konvensi tersebut secara bertahap wajib mewujudkan terselenggaranya jaminan kesehatan bagi

\footnotetext{
${ }^{40}$ Sekretariat Jenderal Dewan Perwakilan Rakyat Republik Indonesia, Proses Pembahasan Rancangan Undang-Undang tentang Sistem Jaminan Sosial Nasional, hlm 27.

${ }^{41} \mathrm{Id}$, hlm 9.

42 Lihat Undang-Undang Nomor 40 tahun 2004 tentang Sistem Jaminan Sosial Nasional Pasal 19 ayat (2).
} 
semua, sesuai dengan kemampuan dan perkembangan negara. ${ }^{43}$ Dalam sidang ke58 tahun 2005 di Jenewa, World Health Assembly (WHA) menggaris bawahi perlunya pengembangan sistem pembiayaan kesehatan yang menjamin tersedianya akses masyarakat terhadap pelayanan kesehatan dan memberikan perlindungan kepada mereka terhadap risiko keuangan. Dalam hal ini Resolusi World Health Assembly ke-58 tahun 2005 merekomendasikan kepada seluruh negara-negara anggota untuk membangun sistem pembiayaan kesehatan yang berkelanjutan guna menjamin pelayanan kesehatan bagi seluruh penduduk, dengan cara: 44

1) Menjamin bahwa sistem pembiayaan kesehatan mengikutsertakan metode pembiayaan pelayanan kesehatan oleh iuran yang dibayarkan di muka, dengan tujuan untuk berbagi risiko di antara penduduk, serta mencegah belanja pelayanan kesehatan yang menimbulkan bencana dan pemiskinan individu karena pengobatan dan perawatan kesehatan;

2) Menjamin ketercukupan dan keadilan distribusi infrastruktur dan sumber daya pelayanan kesehatan yang berkualitas, sehingga Peserta dapat memperoleh pelayanan kesehatan yang berkualitas dan berkeadilan;

3) Menjamin pembiayaan eksternal kegiatan atau program pelayanan kesehatan akan dikelola dan diorganisasikan dengan cara yang mendukung pembangunan pembiayaan kesehatan berkelanjutan untuk keseluruhan sistem kesehatan;

4) Merencanakan transisi menuju cakupan semesta kesehatan warga sehingga mampu memenuhi kebutuhan warga akan pelayanan kesehatan dan peningkatan kualitas pelayanan, menurunkan kemiskinan, mencapai tujuan bersama internasional termasuk tujuan deklarasi pembangunan milenium, dan mencapai kesehatan bagi semua.

\footnotetext{
${ }^{43}$ Hartini Retnaningsih, Tri Rini Puji lestari, Rohani Budi Prihatin, dkk, Jaminan Sosial di Indonesia: Upaya Memberikan Perlindungan Sosial Kepada Masyarakat, Pusat Pengkajian, Pengolahan Data dan Informasi (P3DI) Sekretariat Jenderal DPR Republik Indonesia, Jakarta, 2013, hlm. 31.

${ }^{44}$ Asih Eka Putri, Paham JKN (Jaminan Kesehatan Nasional), Friedrich-Ebert-Stiftung Kantor Perwakilan Indonesia, Jakarta. hlm. 34-35.
} 
5) Di masa peralihan menuju cakupan kesehatan semesta, pilihan-pilihan kebijakan pembiayaan pelayanan kesehatan perlu dibangun sesuai dengan kondisi makro ekonomi, sosiokultur, dan politik masing-masing negara;

6) Berbagi pengalaman tentang berbagai metode pembiayaan kesehatan, termasuk pembiayaan oleh publik, privat, jaminan kesehatan sosial, atau model campuran, dengan perhatian utama pada tata kelola yang dibangun untuk menjalankan fungsi-fungsi pokok sistem pembiayaan kesehatan.

Dalam membangun sistem pembiayaan kesehatan yang berkelanjutan guna menjamin pelayanan kesehatan bagi seluruh penduduk, secara tegas WHA ke-58 mengeluarkan resolusi yang menyatakan, pembiayaan kesehatan yang berkelanjutan melalui Universal Health Coverage diselenggarakan melalui mekanisme asuransi kesehatan sosial. WHA juga menyarankan kepada WHO agar mendorong negara-negara anggota untuk mengevaluasi dampak perubahan sistem pembiayaan kesehatan terhadap pelayanan kesehatan ketika mereka bergerak menuju Universal Health Coverage. ${ }^{45}$

Di Indonesia sendiri hak atas kesehatan termaktub dalam UUD 45 pasal 28H dan pasal 34, dan diatur dalam Undang-Undang Nomor 23 tahun 1992 tentang Kesehatan yang kemudian diganti dengan Undang-Undang Nomor 36 tahun 2009 tentang Kesehatan. Dalam Undang-Undang Nomor 36 tahun 2009 tentang Kesehatan ditegaskan bahwa setiap orang mempunyai hak yang sama dalam memperoleh akses atas sumber daya di bidang kesehatan dan memperoleh pelayanan kesehatan yang aman, bermutu, dan terjangkau. Sebaliknya, setiap orang juga mempunyai kewajiban turut serta dalam program jaminan kesehatan sosial. 46

\section{Prinsip Gotong Royong Pada Jaminan Kesehatan Nasional Dalam Mewujudkan Keadilan Sosial}

Konsep asuransi kesehatan yang diadopsi dalam pelaksanaan Jaminan Kesehatan Nasional bertujuan untuk mengurangi risiko masyarakat menanggung

\footnotetext{
45 Kementerian Kesehatan RI, Buku Pegangan Sosialisasi: Jaminan Kesehatan Nasional (JKN) dalam Sistem Jaminan Sosial Nasional, hlm 8-9.

${ }^{46} \mathrm{Id}, \mathrm{hlm} .9$.
} 
biaya kesehatan dari kantong sendiri out of pocket, dalam jumlah yang sulit diprediksi dan memerlukan biaya yang sangat besar. Untuk itu diperlukan suatu jaminan dalam bentuk asuransi kesehatan dimana peserta membayar premi dengan besaran tetap. Dengan demikian pembiayaan kesehatan ditanggung bersama secara gotong royong oleh keseluruhan peserta, sehingga tidak memberatkan secara orang per orang. ${ }^{47}$ Pembiayaan kesehatan yang ditanggung bersama secara gotong royong sebagaimana dimaksud berlandaskan pada muatan dalam GBHN dan kebijakan Repelita V. Ketentuan Tap MPR nomor II tahun 1988 dan Repelita V 1989/1994 mengamanatkan pengembangan jaminan kesehatan yang berlandaskan pada prinsip asuransi yang secara bertahap mencakup semua warga negara dan penduduk Indonesia. Pada GBHN 1998-2003 diamanatkan bahwa untuk menjamin pemeliharaan kesehatan masyarakat perlu dikembangkan cara pembiayaan kesehatan dengan pendekatan asuransi kesehatan nasional serta upaya memasyarakatkannya berdasarkan prinsip gotong-royong. ${ }^{48}$

Dengan demikian pelaksanaan Jaminan Kesehatan Nasional yang bertujuan untuk mengurangi risiko masyarakat menanggung biaya kesehatan dari kantong sendiri (out of pocket), diupayakan pembiayaan kesehatan yang ditanggung bersama secara gotong royong oleh keseluruhan masyarakat, sehingga tidak memberatkan secara orang per orang. 49 Pembiayaan yang ditanggung secara bersama tersebut secara tidak langsung menciptakan kerjasama sosial antar masyarakat dalam mewujudkan keadilan sosial. Dalam hal ini Jhon Rawls menyatakan bahwa keadilan sosial timbul dalam kondisi yang disebut dengan "kondisi keadilan” (circumstances of justice). Kondisi ini bisa dijelaskan sebagai kondisi dibawah mana kerja sama sosial itu dimungkinkan dan diperlukan, atau syarat-syarat yang mengharuskan perlunya prinsip keadilan yang mengatur pembagian hak dan kewajiban, keuntungan dan beban hasil kerja sama sosial secara adil kepada para warga masyarakat. 50

\footnotetext{
47 Id, hlm. 13

48 Lihat Naskah Akademik Rancangan Undang-Undang Asuransi Kesehatan Nasional, hlm 57-58

49 Kementerian Kesehatan RI, Supra no 45, hlm. 13

50 John Rawls, Teori Keadilan: Dasar-Dasar Filasafat Politik Untuk Mewujudkan Kesejahteraan Sosial Dalam Negara, Pustaka Pelajar, Yogyakarta, 2011, hlm 153-154.
} 
Kendati ada kebutuhan dan kepentingan bersama yang memungkinkan adanya kerja sama sosial yang saling menguntungkan, masyarakat biasanya juga ditandai dengan adanya konflik kepentingan. Adanya konflik kepentingan dikarenakan setiap orang berbeda pandangan atau tidak sepakat dalam hal bagaimana hasil kerjasama sosial dibagi atau didistribusikan. Maka seperangkat prinsip dibutuhkan untuk mengatur cara bagaimana lembaga-lembaga sosial mendistribusikan hasil kerja sama sosial secara adil kepada para warga masyarakat, dalam hal ini prinsip yang dimaksud ialah prinsip keadilan sosial. Subjek utama dari prinsip keadilan sosial adalah struktur dasar masyarakat, tatanan institusi-institusi sosial utama dalam satu skema kerja sama. Dalam hal ini prinsip-prinsip tersebut mengatur pemberian hak dan kewajiban dalam institusi-institusi ini serta menentukan pembagian kenikmatan serta beban kehidupan sosial.51 Dengan demikian dapat dinyatakan bahwa konsepsi keadilan sosial Jhon Rawls dihubungkan langsung dari pandangannya tentang masyarakat sebagai bentuk kerjasama sosial berkelanjutan dari satu generasi ke generasi berikutnya. Ikatan kerja sama sosial didasarkan pada adanya identitas kepentingan bahwa kehidupan yang lebih baik dimungkinkan bagi semua orang dari pada yang bisa didapatkan jika setiap orang berusaha mencukupi kebutuhannya sendiri-sendiri.

Ikatan kerjasama sosial tersebut, dalam jaminan kesehatan nasional diterjemahkan dalam bentuk prinsip gotong royong. Dalam hal ini setiap bentuk upaya kesehatan harus berazaskan perikemanusiaan yang berdasarkan KeTuhanan Yang Maha Esa dengan mengutamakan kepentingan nasional rakyat banyak dan bukan semata-mata kepentingan golongan atau perorangan. Sikap, suasana kekeluargaan, kegotong royongan serta semua potensi yang ada diarahkan dan dimanfaatkan sejauh mungkin untuk pembangunan di bidang kesehatan. Sesuai dengan azas adil dan merata, dimana hasil-hasil yang dicapai dalam pembangunan kesehatan harus dapat dinikmati secara merata oleh seluruh penduduk. 52

\footnotetext{
51 Id, hlm. 65

52 Lihat Naskah Akademik Rancangan Undang-Undang Asuransi Kesehatan Nasional, hlm 1
} 
Dengan demikian konsep gotong royong sebagaimana dimaksud dapat mengurai beban dari masing-masing peserta dalam pembiayaan kesehatan yang cendrung membutuhkan biaya yang cukup tinggi, dimana pembiayaan kesehatan yang tinggi akan akan menyulitkan akses masyarakat terhadap pelayanan kesehatan yang dibutuhkannya, terutama bila pembiayaannya harus ditanggung sendiri (out of pocket) dalam sistem fee for services. Tingginya biaya kesehatan yang harus dikeluarkan oleh perseorangan, menyebabkan tidak semua anggota masyarakat mampu untuk memperoleh pelayanan kesehatan yang layak.

Oleh karena itu kebersamaan antar peserta dalam menanggung beban biaya pelayanan kesehatan, yang diwujudkan dengan kewajiban setiap peserta membayar iuran sesuai dengan tingkat gaji, upah, atau penghasilan bagi pekerja formal dan ketentuan iuran bagi pekerja informal merupakan bentuk gotong royong antar masyarakat (peserta) guna mewujudkan keadilan sosial dalam pelaksanaan jaminan kesehatan nasional bagi seluruh masyarakat.

\section{Penutup}

Hak atas kesehatan sebagai hak mendasar bagi setiap individu secara tegas dinyatakan dalam Undang-Undang Dasar 1945 bahwa setiap orang berhak atas pelayanan kesehatan dan negara bertanggungjawab atas penyediaan fasilitas pelayanan kesehatan. Dengan demikian hak atas kesehatan sebagai hak asasi manusia juga merupakan hak konstitusional rakyat indonesia dimana kesehatan masyarakat sebagai pilar pembangunan sebuah bangsa menuntut peran aktif negara dalam mewujudkannya melalui obligation of conduct dan obligation of result yang merupakan bagian dari pelaksanaan hak-hak ekonomi, sosial, dan budaya.

Hak atas kesehatan yang dirancang dalam konsep asuransi kesehatan sosial disusun sebagai sub sistem dalam Sistem Jaminan Sosial Nasional dimana konsep jaminan sosial akan ditetapkan dalam peraturan yang berbeda, namun pembahasan di DPR menyepakati bahwa Asuransi Kesehatan Sosial di lebur dalam Sistem Jaminan Sosial Nasional. Oleh karena itu jaminan kesehatan melebur dalam program jaminan sosial, hal tersebut tertuang dalam Undang-Undang Nomor 40 
tahun 2004 tentang Sistem Jaminan Sosial Nasional Pasal 18 yang menyatakan bahwa jenis program jaminan sosial meliputi jaminan kesehatan, jaminan kecelakaan kerja, jaminan hari tua, jaminan pensiun, dan jaminan kematian. Dalam hal ini jaminan kesehatan diselenggarakan dengan tujuan menjamin agar peserta memperoleh manfaat pemeliharaan kesehatan dan perlindungan dalam memenuhi kebutuhan dasar kesehatan.

Berdasarkan hal tersebut upaya pemenuhan hak atas kesehatan bagi seluruh masyarakat, Pemerintah menetapkan kebijakan jaminan kesehatan nasional melalui Peraturan Presiden tentang Jaminan Kesehatan yang pembentukannya merupakan perintah dari Undang-Undang Nmor 40 tahun 2004 tentang Sistem Jaminan Sosial Nasional. Dalam hal ini negara merupakan aktor sentral yang memegang tanggung jawab utama dalam pelaksanaan pemenuhan hak atas kesehatan, dimana salah satu indikator dipenuhinya hak atas kesehatan yaitu adanya progressive realization atas tersedia dan terjangkaunya sarana pelayanan kesehatan untuk seluruh masyarakat.

Dalam membangun sistem pembiayaan kesehatan yang berkelanjutan guna menjamin pelayanan kesehatan bagi seluruh masyarakat, maka kerangka pembiayaan dalam jaminan kesehatan nasional dilaksanakan melalui konsep asuransi, dimana masyarakat didorong untuk ikut berperan dalam pembiayaan kesehatan guna mewujudkan pemenuhan hak atas kesehatan. Jaminan kesehatan melalui konsep asuransi kesehatan sosial ditujukan untuk saling membantu antar peserta atau masyarakat dalam mendapatkan kepastian jaminan pelayanan kesehatan bagi peserta atau penduduk Indonesia sehingga dapat terwujud derajat kesehatan masyarakat yang optimal.

Secara konkrit konsep asuransi kesehatan yang diadopsi dalam pelaksanaan jaminan kesehatan nasional bertujuan untuk mengurangi risiko masyarakat menanggung biaya kesehatan dari kantong sendiri out of pocket dalam jumlah yang sulit diprediksi dan umumnya memerlukan biaya yang sangat besar. Dengan demikian jaminan kesehatan nasional diselenggarakan dengan tujuan menjamin agar seluruh masyarakat memperoleh manfaat pemeliharaan kesehatan 
dan perlindungan dalam memenuhi kebutuhan dasar kesehatan agar dapat hidup sehat, produktif, dan sejahtera, sehingga pemenuhan hak atas kesehatan bagi setiap individu dalam perspektif hak asasi manusia terpenuhi.

Di sisi lain pemenuhan hak atas kesehatan dilaksanakan melalui program jaminan kesehatan nasional berlandaskan pada keadilan sosial guna mewujudkan kesejahteraan sosial bagi seluruh masyarakat. Guna mewujudkan keadilan sosial, maka dalam pelaksanaannya jaminan kesehatan nasional memberikan perlakuan yang berbeda bagi setiap individu guna mewujudkan kesetaraan dalam memperoleh pelayanan kesehatan. Kesetaraan dalam memperoleh pelayanan kesehatan dalam kerangka keadilan sosial ditujukan untuk memberikan akses kepada seluruh lapisan masyarakat agar dapat memperoleh pelayanan kesehatan sesuai dengan kebutuhan medisnya (you get what you need). Dalam hal ini bagi peserta yang tergolong miskin dan tidak mampu iurannya dibayarkan oleh Pemerintah yang disebut sebagai penerima bantuan iuran sehingga masyarakat yang tergolong miskin dan tidak mampu tetap dapat menikmati jaminan pelayanan kesehatan tanpa memandang tingkat penghasilan. Dalam hal ini SJSN mengintegrasikan program bantuan sosial dengan program jaminan sosial. Hal tersebut sesuai dengan Undang-Undang Dasar 1945 Pasal 28H ayat (2) yang menyatakan "setiap orang berhak mendapatkan kemudahan dan perlakuan khusus untuk memperoleh kesempatan dan manfaat yang sama guna mencapai persamaan dan keadilan". Dengan demikian penerapan prinsip kepesertaan wajib dan gotong royong dalam hal ini konsep bantuan Pemerintah bagi peserta penerima bantuan iuran dalam jaminan kesehatan nasional, dapat dikatakan sebagai instrument negara dalam mendistribusikan keadilan dalam pemenuhan hak atas kesehatan guna mewujudkan keadilan sosial bagi seluruh masyarakat. 


\section{Daftar Pustaka}

Buku:

Amrah Muslimin, Beberapa Asas dan Pengertian Pokok Tentang Administrasi dan Hukum Administrasi, Alumni, Bandung.

Asih Eka Putri, Paham JKN (Jaminan Kesehatan Nasional), Friedrich-Ebert-Stiftung Kantor Perwakilan Indonesia, Jakarta.

Human Rights Resource Center, Rule of Law untuk Hak Asasi Manusia di Kawasan Asean : Studi Data Awal, Human Right Resource Center

Hendra Nutjahjo, Ilmu Negara: Pengembangan Teori Bernegara dan Supleman, PT. Raja Grafindo Persada, Jakarta.

John Rawls, Teori Keadilan: Dasar-Dasar Filasafat Politik Untuk Mewujudkan Kesejahteraan Sosial Dalam Negara, Pustaka Pelajar, Yogyakarta

James W. Nickel, Making Sense of Human Right, Blackwell Publising, Malden.

Jhon Tobin, The Right to Health in International Law, Oxford University Press, Oxford.

Kementerian Kesehatan RI, Buku Pegangan Sosialisasi: Jaminan Kesehatan Nasional (JKN) dalam Sistem Jaminan Sosial Nasional.

Majda El Muhtaj, Dimensi-Dimensi HAM: Mengurai Hak Ekonomi, Sosial, dan Budaya, Rajawali Pers, Jakarta.

Rhona K.M. Smith, at.al, Hukum Hak Asasi Manusia, PUSHAM UII, Yogyakarta.

Satya Arinanto, Hak Asasi Manusia dalam Transisi Politik di Indonesia, Pusat Studi Hukum Tata Negara Fakultas Hukum Universitas Indonesia, Jakarta.

Tinton Slamet Kurnia, Hak Atas Derajat Kesehatan Optimal Sebagai HAM di Indonesia, PT. Alumni, Bandung.

\section{Jurnal:}

Dedi Afandi, Hak Atas Kesehatan Dalam Perspektif HAM, Jurnal Ilmu Kedokteran Jilid 2 Nomor 1, Jakarta.

Hartini Retnaningsih, Tri Rini Puji lestari, Rohani Budi Prihatin, dkk, Jaminan Sosial di Indonesia: Upaya Memberikan Perlindungan Sosial Kepada Masyarakat, Pusat Pengkajian, Pengolahan Data dan Informasi (P3DI) Sekretariat Jenderal DPR Republik Indonesia, Jakarta.

Paul Hunt, The UN Special Rapporteur on The Right to Health: Key Objectives, Themes, and Intervention, Health and Human Right Vol 7 No.1, The President and Fellows of Harvard College.

Sunaryati Hartono, Membangun Budaya Hukum Pancasila sebagai Bagian dari Sistem Hukum Nasional di Abad 21, 1 Veritas et Justitia, 2015.

Suparman Marzuki, Politik Hukum HAM Di Indonesia, Makalah disampaikan dalam Pelatihan HAM Dasar Bagi Dosen Hukum HAM Se-Indonesia, Surabaya, 10 - 13 Oktober 2011.

Virginia A. Leary, The Right to Health in International Human Right Law, Health and Human Right Vol 1 No.1, The President and Fellows of Harvard College

World Health Organization, 25 Question and Answer on Health and Human Rights, Health and Human Rights Publication Series: Issue No. 1, Geneva. 


\section{Naskah Akademik}

Naskah Akademik Rancangan Undang-Undang Asuransi Kesehatan Nasional.

Sekretariat Jenderal Dewan Perwakilan Rakyat Republik Indonesia, Proses Pembahasan Rancangan Undang-Undang tentang Sistem Jaminan Sosial Nasional.

\section{Ketentuan Internasional}

Universal Declaration Independent of Human Right (Deklarasi Universal Hak Asasi Manusia/DUHAM).

CESCR General Comment No 14: The Right To The Highest Attainable Standard of Health, (Commitee on Social and Cultural Rights, 2000)

Vienna Declaration and Programme of Action adopted at the World Conference on Human Rights, Vienna, 14-25 June 1993, paragraph 5, (United Nations General Assembly document A / CONF. 137/23).

\section{Peraturan Perundang-undangan}

Undang-Undang Nomor 40 tahun 2004 tentang Sistem Jaminan Sosial Nasional.

Undang-Undang Nomor 11 tahun 2005 tentang Pengesahan Internatioanl Covenant on Economic, Social and Cultural Right (Kovenan Internasional tentnag Hak-hak Ekonomi, Sosial dan Budaya).

Undang-Undang Nomor 12 tahun 2005 tentang Pengesahan International Covenant on Civil dan Political Rights (Kovenan Internasional tentang Hakhak Sipil dan Politik).

Undang-Undang Nomor 36 tahun 2009 tentang Kesehatan.

Ketetapan Majelis Pemusyawaratan Rakyat Republik Indonesia Nomor: II/MPR/1993 tentang Garis-Garis Besar Haluan Negara.

Ketetapan Majelis Permusyawaratan Rakyat Republik Indonesia Nomor: $\mathrm{X} / \mathrm{Mpr} / 2001$ tentang Laporan Pelaksanaan Putusan Majelis Permusyawaratan Rakyat Republik Indonesia Oleh Lembaga Tinggi Negara Pada Sidang Tahunan Majelis Permusyawaratan Rakyat Republik Indonesia Tahun 2001. 